\title{
IMMUNOCYTOCHEMICAL STUDY OF TISSUE PARASITISM OF DOG ADRENAL GLANDS IN EXPERIMENTAL CHAGAS' DISEASE
}

\author{
CALIARI M.V.*, LANA M.**, OLIVEIRA E.R.***, BARBOSA A.J.A.**** and TAFURI W.L.***
}

\section{Summary :}

In human beings, the central vein of the adrenal glands has been considered by some authors to be one of the preferential sites of Trypanosoma cruzi settling in the chronic form of Chagas' disease. This appears to be due to the local corticoid-rich environment that may protect the parasite against the immunological defences of the host. An immunocytochemical study of the adrenal glands of 15 dogs was carried out for the detection of tissue parasitism in the acute and chronic phases of experimental T. cruzi infection. No amastigote nests or isolated amastigotes were detected in the adrenal parenchyma or adrenal central vein of the animals studied. Minimal nonspecific inflammatory changes were found in some glands of both infected and noninfected animals. The present results show that the adrenal glands of the dog are not injured and do not constitute a site of escape or reservoir of parasites in experimental Chagas' disease.

KEY WORDS : Chagas' disease. Trypanosoma cruzi. adrenal glands. dog. MOTS CLES : maladie de Chagas. Trypanosoma cruzi. glandes surrénales. chien.

\section{INTRODUCTION}

$\mathrm{n}$ most patients in the chronic phase of Chagas' disease (American trypanosomosis) the number of T. cruzi in tissue is very scarce and inconsistent with the intensity of the inflammatory response that occurs, especially in the heart. These observations have led many authors to propose that the progression of the inflammatory phenomenon in the chronic phase of Chagas' disease, mainly the myocarditis, may occur regardless of the presence of T. cruzi. However, other workers have recently indicated that in some cases of Chagas' disease, the inflammatory lesions of chronic chagasic cardiopathy are associated with the presence of parasites (Almeida et al., 1981; Barbosa et

* Departamento de Patologia Geral, Instituto de Ciências Biológicas, Universidade Federal de Minas Gerais.

** Departamento de Análises Clínicas, Escola de Farmácia, Universidade Federal de Ouro Preto.

*** Departamento de Ciências Biológicas, Instituto de Ciências Biológicas, Universidade Federal de Ouro Preto.

**** Departamento de Anatomia Patológica e Medicina Legal, Faculdade de Medicina, Universidade Federal de Minas Gerais.

Address for correspondence : Prof. Marcelo Vidigal Caliari, Depto. de Patologia Geral, Instituto de Ciências Biológicas, Universidade Federal de Minas Gerais. Av. Antônio Carlos 6627, Pampulha, Belo Horizonte-MG-Brasil. 31.270.010; Fax (031) 441-1412.

Supported by CNPq, FAPEMIG and FINEP.
Résumé : ÉTUDE IMMUNOCYTOCHIMIQUE DU PARASITISME TISSULAIRE DH

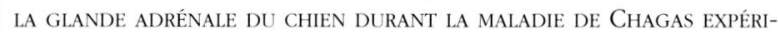
MENTALE.

Chez l'humain, la veine centrale de la glande adrénale est considérée par certains auteurs comme un des sites préférentiels de l'établissement de Trypanosoma cruzi durant la phase chronique de la maladie de Chagas. Cela semble dû à l'environnement local riche en corticoides qui peut protéger le parasite contre les défenses immunologiques de l'hôte. Une étude immunocytochimique des glandes adrénales de 15 chiens a été conduite pour détecter le parasitisme tissulaire des phases aiguë et chronique de l'infection expérimentale par Trypanosoma cruzi. Aucun nid d'amastigote ou amastigote isolé n'a pu être détecté dans le parenchyme adrénal ou la veine adrénale centrale des animaux étudiés. Des changements inflammatoires non spécifiques minimaux ont été trouvés dans quelques glandes d'animaux infectés ou non. Les résultats obtenus ici montrent que les glandes adrénales du chien ne sont pas lésées et ne constituent pas un site d'échappement ou un réservoir des parasites lors de la maladie de Chagas expérimentale.

al., 1986; Higuchi et al., 1993). Therefore, the possibility of the existence of a reservoir of $T$. cruzi in host tissues that may act as a source of periodic discharge parasite, would be very important for the study of the pathogenesis of Chagas' disease. Examining this possibility in human chronic Chagas' disease, Teixeira et al. (1986) observed intense parasitism on the adrenal gland central vein wall, which differed from the myocardium and other tissues examined. It was then hypothesized that the glucocorticoid-rich environment of the adrenal glands may explain the preferential tropism of T. cruzi for this site, allowing its perpetuation in host tissues and then representing a factor responsible for the progression of chronic myocarditis. However, in a study of adrenal glands of rats with experimental trypanosomiasis, Machado et al. (1990) obtained discordant results.

The objective of the present investigation was to study the parasitism of the central vein and parenchyma of adrenal glands in dogs inoculated with the Be- 62 and Be-78 strains of T. cruzi and killed during the acute and chronic phases of the disease. The dog, in contrast to the rat, can develop a chronic cardiomyopathy with an anatomoclinical pattern similar to that observed in human beings (Lana et al., 1992; Lana et al., 1988; Tafuri et al., 1988) and thus it may be considered a 

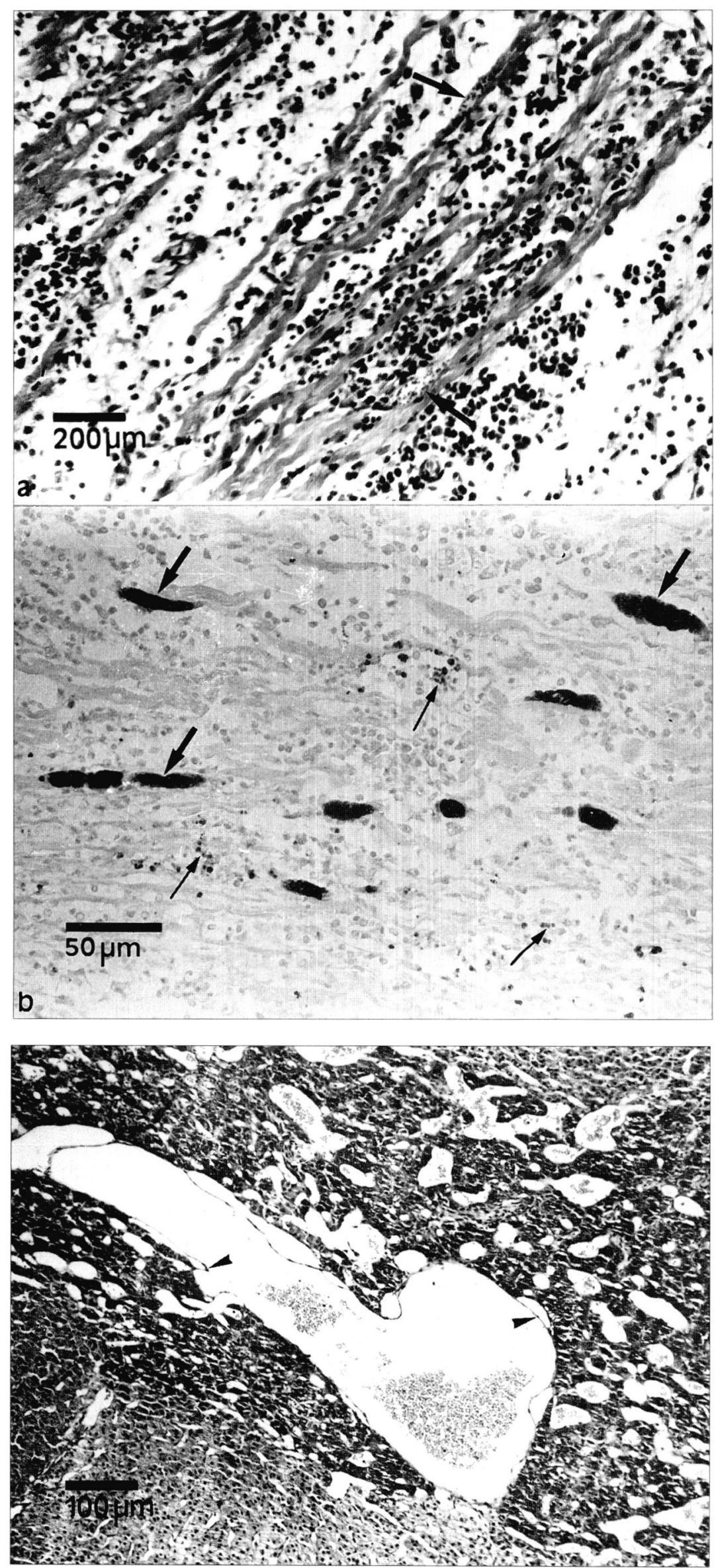

Fig. 1. - Dog inoculated with the Be-78 strain of T. cruzi and killed during the acute phase of the infection. (a) Acute, diffuse myocarditis with intense exsudation of mononuclear cells and amastigote nests (arrows). (b) Presence of strongly stained clusters of amastigotes (large arrows) and numerous isolated form of amastigotes (small arrows) scattered through out the section of cardiac fibers. a. HE staining; b. PAP staining.
Fig. 2. - Dog inoculated with the Be-78 strain of T. cruzi and killed during the acute phase of the infection. Medullar and cortical regions of adrenal gland showing the central vein (arrowheads) without parasites or inflammation. HE staining. 
more suitable animal model for the study of adrenal gland parasitism and its possible role as a T. cruzi tissue reservoir in the chronic phase of Chagas' disease as it is supposed to occur in human disease.

\section{MATERIALS AND METHODS}

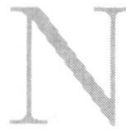
ineteen young mongrel dogs (65-80 days old) born and kept under experimental conditions were used. Fifteen dogs were inoculated with 2,000 metacyclic trypomastigotes/kg weight by the conjunctival route, six with the Be-62 strain and nine with the Be-78 strain. These two different strains of $T$. cruzi were isolated from patient Berenice in 1962 and 1978, respectively (Salgado et al., 1962; Lana \& Chiari, 1986). Berenice is considered to be the first reported human case of Chagas' disease (Chagas, 1909). Four dogs served as control. The animals were kept on an ad libitum diet and under daily observation in an appropriate kennel. Parasitemia was evaluated daily during the acute phase by parasite counts in fresh blood (Brener, 1962). Eleven dogs, four inoculated with the Be-62 strain and seven with the Be-78 strain, were killed 37 to 44 days after inoculation (acute phase) and submitted to necropsy. The other four dogs, two inoculated with Be-62 and two with Be-78, were sacrificed 3 to 66 months after infection.

The adrenal glands were collected in toto, fixed in buffered neutral formaldehyde, and processed for paraffin embedding. A total of $1204 \mu \mathrm{m}$ thick sections were obtained from each pair of glands; 60 of them were stained with hematoxylin and eosin (HE) for histological analysis and the other 60 were stained by the peroxidase-antiperoxidase (PAP) method (Barbosa, 1985) for specific staining of T. cruzi. Antiserum produced in rabbits against the CL strain of T. cruzi was used at 1/1,000 dilution. HE-stained sections were examined for both inflammatory reaction and amastigote nests, while the PAP-stained sections were used to determine and evaluate the presence of amastigotes in tissue. Previous work had shown that the PAP method is more sensitive than HE for amastigote quantification in tissue sections (Barbosa, 1986). Several paraffin sections of the heart atrial wall were used for histopathological analysis of the myocardium (HE staining) and for evaluation of tissue parasitism (PAP staining).

\section{RESULTS}

cute myocarditis characterized by diffuse or multiple foci of mononuclear cells was observed in all dogs sacrified during the acute phase of the disease. In these animals the cardiac fibers presented abundant T. cruzi parasitism that was well defined by both staining procedures, HE and PAP (fig. $1 \mathrm{~A}$ and B). The two dogs inoculated with the Be-78 strain and killed during the chronic phase of the disease presented chronic fibrous myocarditis with sparse tissue parasitism only visualized in PAP-stained sections. In the animals inoculated with the Be-62 strain and killed during the chronic phase, neither cardiac fibrosis nor parasitism was observed although small foci of myocarditis could be detected. T. cruzi parasitism was not detected in the adrenal glands of any animals killed during the acute or chronic phase of Chagas' disease (fig. 2). Small foci of mononuclear inflammatory cells were observed in parenchyma of the glands of a few animals of both the chagasic and non-chagasic groups.

\section{DISCUSSION}

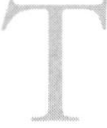

he human adrenal glands present a central vein with a well developed smooth muscle layer that appears to be the most intensely parasitized tissue in human chronic Chagas' disease (Almeida et al., 1981; Teixeira et al., 1986). In contrast, the central vein of the rat adrenal gland is very delicate, without a distinguishable muscle coat and this may explain the negative results obtained in studies of adrenal parasitism during the chronic phase of experimental trypanosomosis cruzi in rats (Machado et al., 1990). A very delicate central adrenal vein containing a hardly developed smooth muscle layer was also observed in the dogs studied here. However, while Machado et al. (1990) found intense parasitism during the acute phase in rat adrenal glands, we could not detect the presence of Trypanosoma cruzi in the adrenal tissues of dogs either in the acute or the chronic phase. Machado et al. (1990) concluded that their results did not support the hypothesis that the corticoid-rich environment would favour local T. cruzi colonization. The present results led us to reach the same conclusion. Nevertheless, we do not know if our results were influenced by the scarceness of smooth muscle fibers in the adrenal central vein. Therefore, even though we can not exclude completely the hypothesis of Almeida et al. (1981) and Teixeira et al. (1986) concerning the adrenal parasitism in human Chagas' disease, other organs from different animals should be studied to conclude for eventual sites of $T$. cruzi predilection. In addition, the ecological interaction between different strains of $T$. cruzi with different animal species should be better studied. In the Brazilian opossum Didelphis albiventris inoculated 
with T. cruzi, we have observed tissue parasitism without any evidence of an inflammatory reaction (unpublished data).

The present results indicate that in canine experimental trypanosomiasis cruzi the adrenals glands do not present either parasites or histopathological changes resulting from the presence of $T$. cruzi. Therefore, we may conclude that these glands are not a preferential site for parasite survival and escape from the host defences. This negative finding is more significant if we consider that two dogs in the chronic phase developed cardiac lesions similar to those observed in human chagasic cardiopathy. Thus, the local corticoid-rich environment may not be sufficient to explain the frequent parasitism observed in the adrenal glands of some patients with chronic chagasic cardiopathy.

\section{REFERENCES}

Almeida H.O., Teixeira V.P.A., Oliveira A.C.F. Flebite com parasitismo em supra-renais de chagásicos crônicos. Arquives Brasileiros de Cardiologia, 1981, 36, 341-344.

Barbosa A.J.A. : Método imunocitoquímico para a identificação de amastigotas do Trypanosoma cruzi em cortes histológicos de rotina. Revista do Instituto de Medicina Tropical de São Paulo, 1985, 27, 293-297.

Barbosa A.J.A., Gobbi H., Lino B.T., Lages-Silva E., Ramirez L.E., Teixeira V.P.A. and Almeida H.O. Estudo comparativo entre o método convencional e o de Peroxidaseantiperoxidase na pesquisa do parasitismo tissular na cardiopatia chagásica crônica. Revista da Sociedade Brasileira de Medicina Tropical, 1986, 28, 91-96.

BRENER Z. Therapeutic activity and criterion of cure on mice experimentally infected with Trypanosoma cruzi. Revista do Instituto de Medicina Tropical de Sào Paulo, 1962, 4, 389-396.

Chagas C. Nova tripanosomiase humana. Estudos sobre a morfologia e ciclo evolutivo do Schizotrypanum cruzi $\mathrm{n}$. gen., n. sp., agente etiológico de nova entidade mórbida do homem. Memórias do Instituto Oswaldo Cruz, 1909, 1, 159-218.

Higuchi M.L., De Brito T., Reis M.M., Barbosa A.J.A., Bellotti G., Pereira-Barreto A.C. and Pileggi F. Correlation between Trypanosoma cruzi parasitism and myocardial inflammatory infiltrate in human chronic chagasic myocarditis. Light microscopy and immunohistochemical findings. Cardiovascular Pathology, 1993, 2, 101-106.

LANA M. and Chiari C. de A. Caracterização biológica comparativa das cepas Berenice-62 e Berenice-78 de Trypanosoma cruzi, isoladas da mesma paciente em diferentes periodos. Memórias do Instituto Oswaldo Cruz, $1986,81,247-253$.

Lana M., Chiari E. and Tafuri W.L. Experimental Chagas' disease in dogs. Mem. Inst. Oswaldo Cruz, 1992, 87, 5971.

lana M., Tafuri W.L., Caliari M.V., Bambirra E.A., Chiari C. de A., Rios Leite V.H., Barbosa A.J.A., Toledo M.J.O. and Chiari E. Fase crónica cardíaca fibrosante da tripanosomíase cruzi experimental no cão. Revista da Sociedade Brasileira de Medicina Tropical, 1988, 21, 113-121.

Machado L.R., Machado C.R.S., Cardoso J.E. and Barbosa A.J.A. Rat adrenal gland in experimental american trypanosomiasis : immunocytochemical study of tissue parasitism. Annales de Parasitologie Humaine et Comparée, 1990, 65, 126-130.

Salgado J.A., Garcez P.N., Oliveira C.A. and Galizzi J. Revisão clínica atual do primeiro caso humano descrito de doença de Chagas. Revista do Instituto de Medicina Tropical de São Paulo, 1962, 4, 330-337.

Tafuri W.L., lana M. De, Chiari E., Caliari M.V., Bambirra E.A., Rios Leite V.H. and Barbosa A.J.A. O Cão como modelo experimental para o estudo da história natural da doença de Chagas. Revista da Sociedade Brasileira de Medicina Tropical, 1988, 21, 77.

Teixeira V.P.A., Fernandes P.A., Brandão M.C., Gobbi H., Reis M.A. and Almeida H.O. Parasitismo incomum na veia central da supra-renal em chagásicos crônicos. Arquives Brasileiros de Cardiologia, 1986, 47, 425-428.

Accepté le 17 octobre 1994 